\title{
GLOBAL SOLAR RADIATION INTERCEPTION BY GRAPEVINES TRAINED TO A VERTICAL TRELLIS SYSTEM ${ }^{1}$
}

\author{
CLAUDIA GUIMARÃES CAMARGO CAMPOS², LUCIANE ISABEL MALINOVSKI ${ }^{3}$, \\ HAMILTON JUSTINO VIEIRA ${ }^{4}$, APARECIDO LIMA DA SILVA ${ }^{5}$
}

\begin{abstract}
In this paper we assess the utilization of radiant energy in the growing of grapevines (Cabernet Sauvignon) trained to a vertical trellis system, and estimate the global solar radiation interception taking into account the physical characteristics of the training system at different phenological stages. The experiment was based on daily measurements of global solar radiation made by an automatic weather station placed at the vineyard of a winery located in the municipality of São Joaquim, in the southern Brazilian State of Santa Catarina (Villa Francioni winery, $28^{\circ} 15^{\prime} 14^{\prime \prime} \mathrm{S}$, 49 $9^{\circ} 57^{\prime} 02^{\prime}$ W, $1294 \mathrm{~m}$ a.s.1.). Growth and phenological development of the shoots were evaluated. The global solar radiation is intercepted by the canopy (trained to a vertical trellis system) in different orientations and the accumulated total is slightly greater on the east than on the west face of the canopy, especially after flowering. The daily variability of global solar radiation intercepted by the canopy is greater after flowering. The accumulated solar energy incident on the canopy increases until the onset of ripening. From the results, vineyards trained to a vertical trellis system in the north-south direction provide favorable sunlight exposure to leaves and fruits and are promising in quality and productivity.
\end{abstract}

Index terms: Vitis vinifera L., vegetative growth, climatology.

\section{INTERCEPTAÇÃO DA RADIAÇÃO SOLAR GLOBAL PELA CULTURA DA VIDEIRA CONDUZIDA EM ESPALDEIRA}

RESUMO - O presente trabalho avaliou e estimou o aproveitamento da radiação solar global para o crescimento da videira cv. Cabernet Sauvignon, conduzida em espaldeira, por meio da interceptação da radiação solar global, considerando as características físicas da forma de condução do dossel em suas diferentes fases fenológicas. Para isto, utilizaram-se valores diários de radiação solar global (MJ.dia-1) obtidos da estação meteorológica automática instalada no vinhedo da Vinícola Villa Francioni, localizada

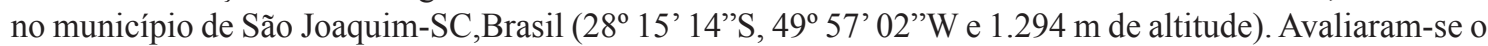
desenvolvimento fenológico e o crescimento dos ramos. A radiação solar global é interceptada pelo dossel em suas diferentes orientações, sendo que o total acumulado de radiação solar interceptada foi levemente maior no sensor de leste em relação ao sensor de oeste, especialmente após a floração. A variabilidade diária da radiação solar global interceptada pelo dossel é maior após a floração. O acúmulo de energia solar ocorre em ascendência até o início da maturação nas diferentes faces do dossel. Os resultados mostram que os vinhedos conduzidos em espaldeira, no sentido norte-sul, proporcionam favorável exposição solar das folhas e frutos, revelando-se promissores em qualidade e produtividade.

Termos para indexação: Vitis vinifera L., crescimento vegetativo, climatologia.

(Trabalho 078-15). Recebido em:09-03-2015. Aceito para publicação em: 18-11-2015.

${ }^{2}$ Meteorologista, DSc., Professora, UDESC/CAV, Lages-SC, E-mail: claudia.campos@udesc.br

${ }^{3}$ Enga. Agra., DSc., Bolsista PNPD/CAPES, UFSC/EPAGRI/Ciram, Florianópolis-SC. E-mail: lucianeisabel@yahoo.com.br ${ }^{4}$ Eng. Agr., DSc., Pesquisador, EPAGRI/Ciram, Florianópolis-SC. E-mail: hjvieira@gmail.com

${ }^{5}$ Eng. Agr., DSc., Professor, Universidade Federal de Santa Catarina, UFSC/RGV, Florianópolis-SC, E-mail: alsilva@ufsc.br 


\section{INTRODUCTION}

Solar radiation is a primary source of energy for the environment and for plant development through photosynthesis. In addition to determining the timings of grapevine flowering and fruit set, it is also related with the physico-chemical characteristics of grapes and consequently the quality of wines (SONG et al., 2015).

Knowledge of the phenological events as well as its relations with sunlight availability is a relevant factor in plant adaptation to local conditions (SANTOS, 2006) whereas sunlight availability varies according to geographical location (VIEIRA et al., 2011; BRIGHENTI et al., 2015).

Carbohydrate reserves accumulated during the previous growing cycle (the one prior to last winter dormancy) are used to start the process of shoot growth. When leaves become fully functional, grapevines begin to photosynthesize its nutrients and no longer depend on those reserves to continue to grow. The developmental progression of a grapevine is described by a sigmoid curve where growth is initially slow, then fast (during the flowering period), then slow again (SCARPARE, 2007; BORGHEZAN et al., 2014).

During budburst, shoots and leaves develop rapidly (BORGHEZAN et al., 2014). Sunlight is indispensable in the flowering and fruit set stages, which are important phenological periods. The intensity of solar radiation affects bud fertility. A number of studies have shown that shading can diminish fertility (SRINIVASAN, MULLINS, 2000). After flowering, grape bunches are formed and begin to develop simultaneously with shoots. From this point, most of the carbohydrate supply is now diverted to the developing berries.

As the grapes mature, the occurrence of sunny days greatly increases the accumulation of sugars (photosynthesized in the leaves) within the berries. In particular, for good crop yields, the period from veraison to ripening must have enough solar radiation availability (PEDRO JÚNIOR, SENTELHAS, 2003).

According to Smithyman et al. (1997), direct sunlight penetration in the canopy, in addition to increasing the photosynthetic efficiency, is beneficial to bunch formation, bud differentiation, berry fixation, grape composition and quantity, and to reducing the incidence of fungal deseases.

Maximum photosynthetic efficiency requires between 150 and $200 \mathrm{~W} \cdot \mathrm{m}^{-2}$ of light intensity and is strongly affected by the environmental conditions under which the leaves develop. Efficiency decreases if shading occurs and increases if leaves are directly exposed to sunlight (ASSIS et al., 2004). For example, in a pergola, where the uppermost foliage is directly exposed to sunlight but the lower foliage receives only diffuse light, some of its leaves may become yellowish and eventually fall off the vines. Such problem are minimized in training systems with less foliage layers to allow a larger foliage area to be exposed to direct insolation (EMBRAPA, 2003).

The choice of an appropriate training system that maximizes sunlight exposure is a key factor for best plant development (REYNOLDS, HEUVEL, 2009). Changes in direction, height, and spacing of rows can alter the total foliage area exposed and consequently its photosynthetic capacity. The amount of solar radiation absorbed by the canopy determines crop productivity and grape quality (BRIGHENTI et al., 2015) and exerts an effect on the physiological response and development of grapevines (PONI, 2005). Better exposed training systems are more efficient in producing fruits of improved quality (PONI, CASALIN, 2005).

In this study we assess the utilization of radiant energy in the growing of grapevines (Cabernet Sauvignon) trained to a vertical trellis system, and estimate the global solar radiation interception taking into account the physical characteristics of the training system at different phenological stages.

\section{MATERIALS AND METHODS}

The experiment was based on daily measurements of global solar radiation made by an automatic weather station placed at the vineyard of a winery located in the municipality of São Joaquim, in the southern Brazilian State of Santa Catarina (Villa Francioni winery, 28 $18^{\circ}$ ' $14^{\prime \prime} \mathrm{S}, 49^{\circ} 57^{\prime} 02^{\prime \prime}$ $\mathrm{W}, 1294 \mathrm{~m}$ a.s.1.). The region is classified as $C f b$ in the Köppen climate scheme (humid subtropical).

The State of Santa Catarina has a variety of regional climates due to its geographical position, its terrain, and the influence of distinct meteorological systems. Particularly in São Joaquim, the climate is characterized by low air temperatures, high availability of chilling hours, and regular yearly rainfall (more frequent in spring and summer). January and February are the hottest months (about $17^{\circ} \mathrm{C}$ ), and July the coldest (about $9.4^{\circ} \mathrm{C}$ ). Such characteristics, despite the occurrence of frequent frosts, explain the increasing number of wine grape farms in the region because of its favorable climatic pattern (BORGHEZAN et al., 2014).

Two sensors of the weather station (CUV3 Kipp and Zonen radiometers connected to a CR1000 
Campbell Scientific datalogger) were placed near the canopy, facing east (E) and west (W), respectively, at $1.6 \mathrm{~m}$ above ground. A third sensor was placed above the canopy, facing upwards, at $3 \mathrm{~m}$ above ground. Readings were made between October 2008 and December 2011.

The vineyard was planted in 2002 with the Cabernet Sauvignon variety grafted onto Paulsen 1103 rootstock and trained to a north-south-oriented vertical trellis system with line spacing of $3 \mathrm{~m}$ and plant spacing of $1 \mathrm{~m}$ (BORGHEZAN et al., 2012). Initially, considering the spatial characteristics of the training system, a lateral area of $1.5 \mathrm{~m}^{2}(1 \mathrm{~m}$ wide $\mathrm{X}$ $1.5 \mathrm{~m}$ high) relative to the east and west faces of the canopy was delimited, plus an area of $0.2 \mathrm{~m}^{2}$ relative to the top of the canopy. Also, an area of $3 \mathrm{~m}^{2}$ was delimited for sunlight exposure in order to simulate a pergola system. Once the areas for vine growth were defined, they were associated with the average growth rate of shoots during three phenological stages: budburst to flowering (15/Sep to $27 / \mathrm{Nov})$, flowering to ripening (27/Nov to $6 / \mathrm{Feb})$, and ripening (6/Feb to harvest).

After defining the relative growth index, the amount of the daily global solar radiation flux interception by the canopy during the phenological stages was found by summation of the measured global solar radiation fluxes incident on the east, west, and top faces of the canopy.

Results were subjected to analysis of variance and the significant characteristics were subjected to Tukey's test at a 5\% probability.

\section{RESULTS AND DISCUSSION}

Estimation equations were calculated to describe the relation between shoot growth (maximum average growth of $3.2 \mathrm{~m}$ ) and the occupied area $\left(1.5 \mathrm{~m}^{2}\right.$ on lateral faces $+0.2 \mathrm{~m}^{2}$ on top of the canopy) during the phenological cycle of the grapevines, as shown in Figure 1. Fitting of the data revealed an excelent correlation in both cases, with a coefficient above 0.98 indicating high accuracy of the selected equations.

The maximum relative growth $(0.59 \mathrm{~m})$ was observed near the $73^{\text {rd }}$ day after budburst, in late November (flowering), when $46 \%$ of the available area for shoot growth was occupied by the canopy (Table 1). In January, when $80 \%$ of the area was occupied, sunlight was reduced in the interior of the canopy. It should be noted the high relation between shoot growth and the solar radiation flux (coefficient of 0.97 ) considering the time interval starting when shoots began to grow (after budburst) until the onset of ripening, when shoot growth began to diminish (144 days). Moreover, between flowering and the onset of ripening (November to February), the solar radiation intercepted by the canopy varied from $27 \%$, in the beginning, to $81 \%$, at the end of the period, as observed by Campos et al., (2013).

Subsequently, the relative growth decreased and $100 \%$ of the area was occupied in late February, when maximum solar radiation was intercepted by the plants. From this point, the apparent movement of the sun caused a reduction in the available light, since the area was totally occupied by the canopy. Borghezan et al., (2014) observed similar events and concluded that shoot growth cessation is influenced by reduction of the photoperiod.

Using the relative growth index, the daily global solar radiation intercepted by the canopy along the phenological stages was verified. It was estimated based on the radiation interception on the east, west, and top faces of the canopy (which was trained to a vertical trellis system). The radiation that falls upon the crop was considered the radiation available to the crop. Results showed that the bigger the area occupied by the canopy during the phenological development, the greater the intercepted daily global solar radiation. The greatest average values of intercepted daily global solar radiation were observed between flowering and the onset of ripening. During this period, a greater amount of solar radiation reaches the atmosphere at the considered latitude (VIEIRA et al., 2011). Thus, the relative growth indices for all canopy faces are not significantly different, by Tukey's test at a 5\% probability.

From mid-February (144 days after budburst), the daily global solar radiation tends to diminish, shoot growth stops, and berries begin to ripen. Campos et al., (2013) also reported similar events. According to Borghezan (2001), this is when the shoots begin to lignify, the lateral buds stop developing, and the leaves become senescent (begin to age). Cloete et al. (2006), who also described this behavior, state that shoot growth cessation at the onset of ripening is beneficial to the accumulation of compounds within the berries that improve grape quality.

During the ripening stage, the daily variability of the intercepted solar radiation tends to diminish on the east, west and top faces of the canopy (Figure 2). According to Caron et al., (2012), the energy provided by the intercepted solar radiation determines the photosynthetic rate. Limited biomass build-up, plant development, and productivity may result from lack of this energy. We can thus conclude that plant 
development is boosted (and the intercepting foliage area increases) with increased global solar radiation and stabilizes at the onset of ripening. The effects of solar radiation interception determines productivity and grape quality (EMBRAPA, 2003)

According to Cardoso et al., (2010), solar radiation interception may be influenced by the adopted training system. In vineyards trained to a vertical trellis system, the global solar radiation is intercepted by the canopy in different orientations and the total accumulated solar radiation interception is slightly greater on the east than on the west face of the canopy, especially after flowering.

At the onset of ripening, the canopy intercepted an accumulated daily global solar radiation of 810 MJ on the east face; $643 \mathrm{MJ}$ on the west face (Figure 3 ); and $273 \mathrm{MJ}$ on the top face (smaller area). By summation of the three contributions, the canopy intercepted a total accumulated global solar radiation of $3440 \mathrm{MJ}$ at the end of the growing cycle.

When simulating a pergola system with an exposure area of $3 \mathrm{~m}^{2}$, the canopy intercepted a total global solar radiation of 7830. day $^{-1}$, twice as great as the total accumulated solar radiation intercepted by a canopy trained to a vertical trellis system (total area of $1.5 \mathrm{~m}^{2}$ ). This result is observed especially between September and early February, as shown in Figure 1 and last column of Table 1. However, the horizontal canopy and the excessive vigor of the vines may cause shading and affect the microclimate, the fertility of buds, and the quality of grape and wine. (MIELE; MANDELLI, 2003).

The grapevines trained to a vertical trellis system intercepts only $50 \%$ of the global solar radiation incident on a pergola. These indices show that solar radiation interception may be optimized by changing row spacing. Given a spacing of $1 \mathrm{~m}$ X $3 \mathrm{~m}$ $\mathrm{X} 1.5 \mathrm{~m}$ (canopy height), the intercepting canopy area during the ripening stage would be $3 \mathrm{~m}^{2}$, the same as the area occupied by a plant. Thus, from the results relative to solar radiation, we suggest increasing plant density by reducing row spacing (the use of smaller vineyard machinery would be a side benefit) to enhance plant productivity. Thus, further studies are required to investigate plant density on vineyard microclimate, particularly the water dynamics within the soil-plant-atmosphere system, and consequently the incidence of deseases that depend on atmospheric conditions.

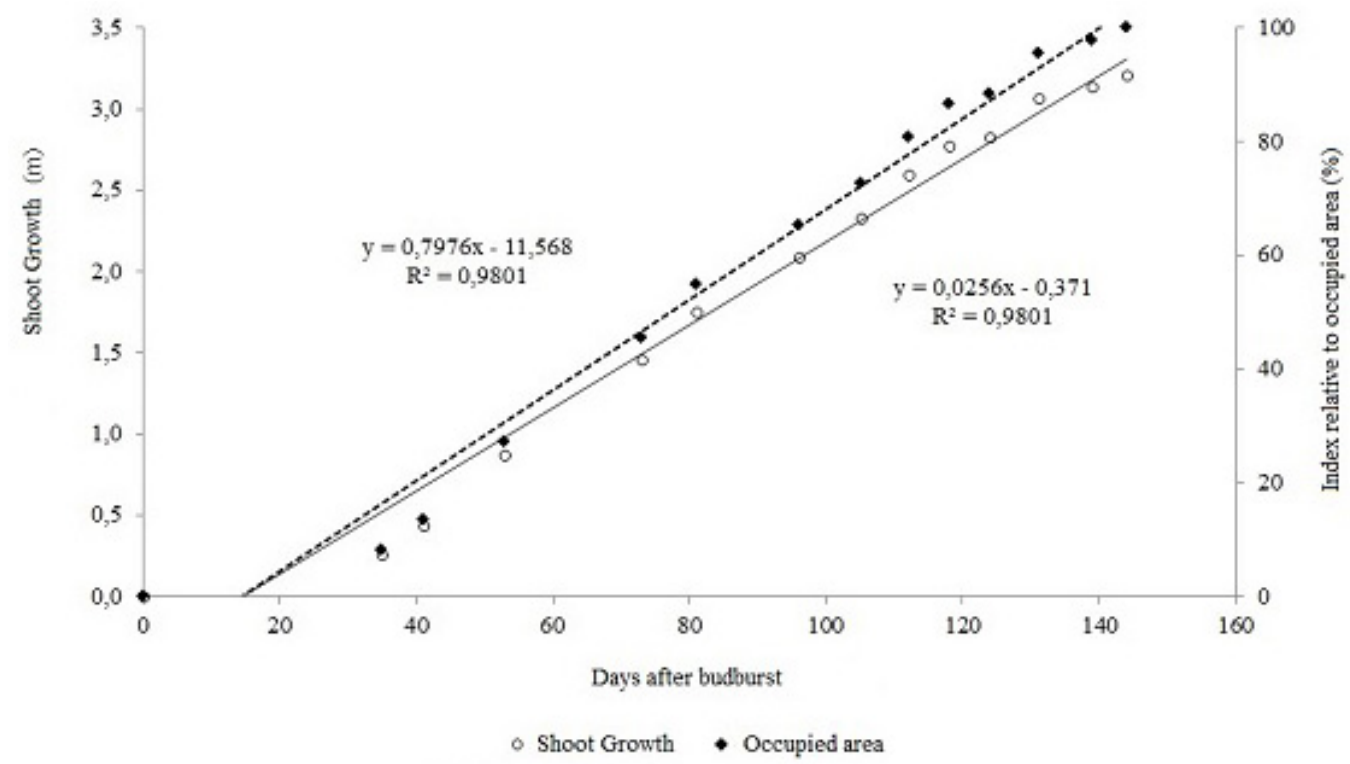

FIGURE 1 - Relative indices between shoot growth (m), vine phenological cycle, and percentage of occupied area. São Joaquim, SC, Brazil. 2010-2011 growing cycle. 
TABLE 1 - Mean and relative shoot growth and occupied area of altitude vineyards trained to a vertical trellis system. São Joaquim, SC, Brazil. 2010-2011 growing cycle.

\begin{tabular}{c|c|c|cc}
\hline Date & Duration (days) & $\begin{array}{c}\text { Shoot lenght } \\
(\mathbf{m})\end{array}$ & $\begin{array}{c}\text { Relative growth } \\
(\mathbf{m})\end{array}$ & $\begin{array}{c}\text { Occupied area } \\
(\mathbf{\%})\end{array}$ \\
\hline \multicolumn{5}{c}{ Budburst to flowering } \\
\hline 15/sep & 0 & 0 & 0 & 0 \\
20/oct & 35 & 0.26 & 0.26 & 8 \\
26/oct & 41 & 0.44 & 0.17 & 14 \\
07/nov & 53 & 0.87 & 0.44 & 27 \\
\hline \multicolumn{5}{r}{ Flowering to ripening } \\
\hline 27/nov & 73 & 1.46 & 0.59 & 46 \\
05/dec & 81 & 1.76 & 0.30 & 55 \\
20/dec & 96 & 2.09 & 0.33 & 65 \\
29/dec & 105 & 2.33 & 0.24 & 73 \\
05/jan & 112 & 2.59 & 0.26 & 81 \\
11/jan & 118 & 2.78 & 0.18 & 87 \\
17/jan & 124 & 2.83 & 0.05 & 88 \\
24/jan & 131 & 3.07 & 0.23 & 96 \\
01/feb & 139 & 3.14 & 0.07 & 98 \\
06/feb & 144 & 3.21 & 0,07 & 100 \\
\hline \hline
\end{tabular}

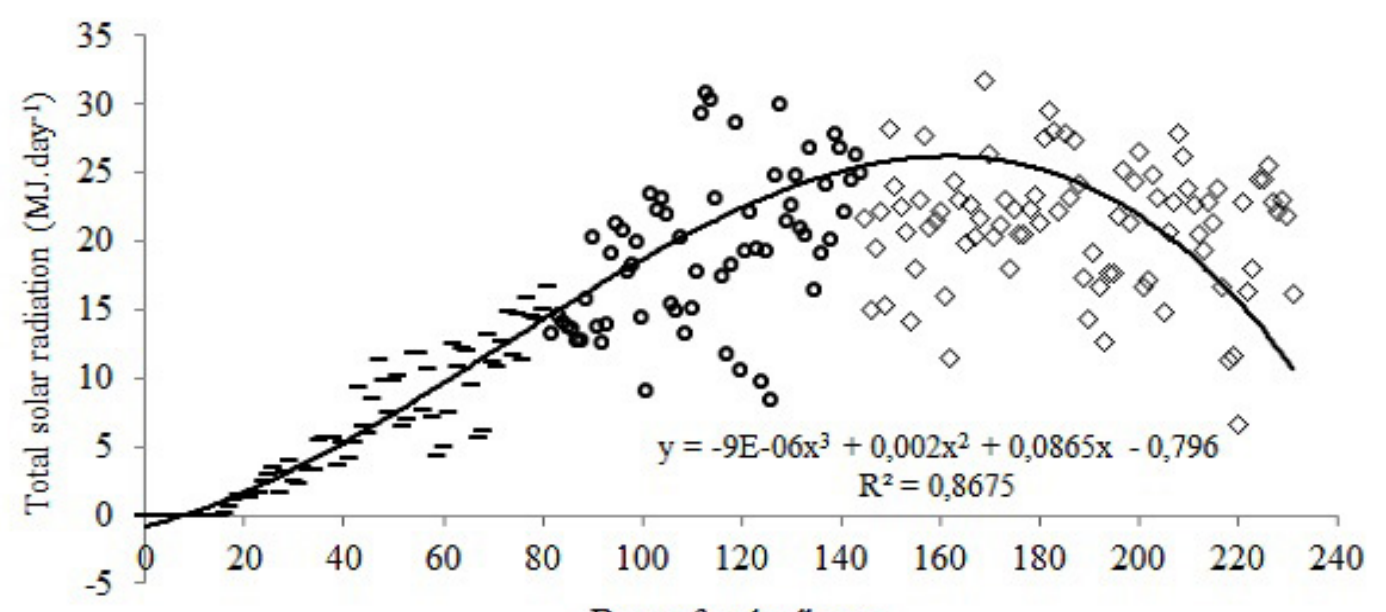

Days after budburst

- Budburst to flowering $\quad$ Flowering to ripening $\diamond$ Ripening

FIGURE 2 - Estimation of global solar radiation intercepted by a grapevine trained to a vertical trellis system considering the total global solar radiation incident on the east, west, and top faces of the canopy. São Joaquim, SC, Brazil. 2010-2011 growing cycle. 


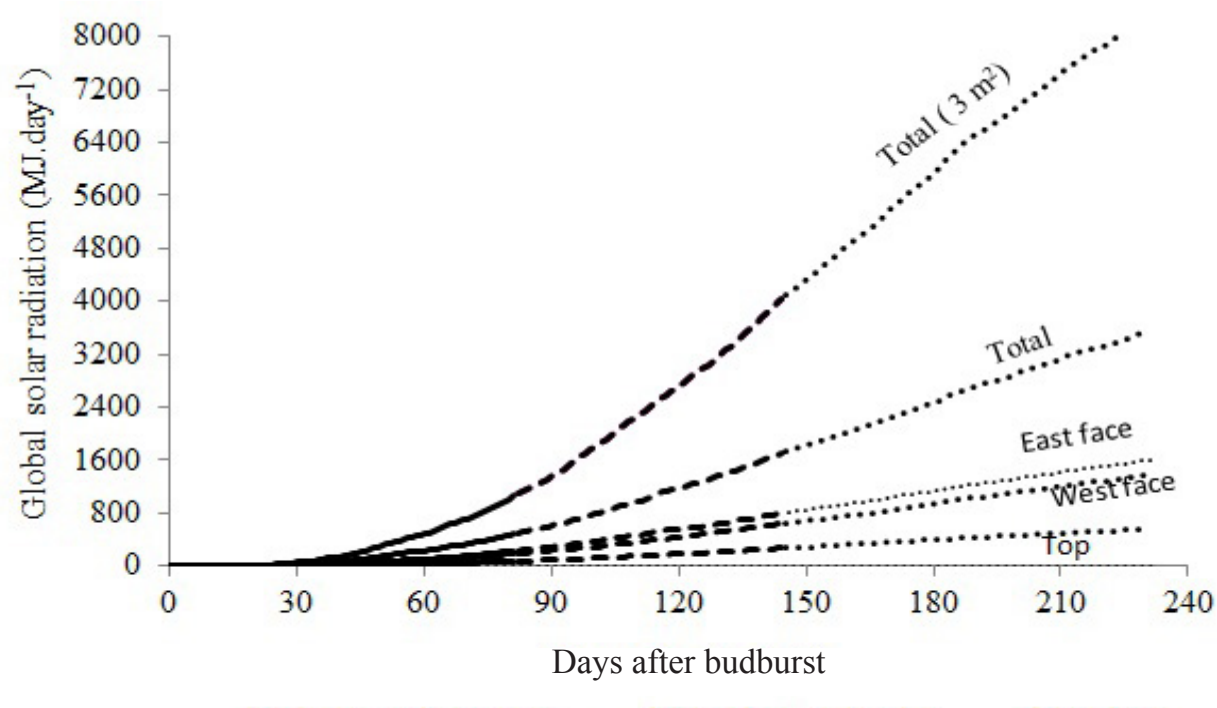

FIGURE 3 - Estimation of accumulated global solar radiation intercepted by a grapevine trained to a vertical trellis system and to a pergola system (total area of $3 \mathrm{~m}^{2}$ ). São Joaquim, SC, Brazil. 2010-2011 growing cycle.

\section{CONCLUSION}

The global solar radiation is intercepted by the canopy (trained to a vertical trellis system) in different orientations and the accumulated total is slightly greater on the east than on the west face of the canopy, especially after flowering.

The daily variability of global solar radiation intercepted by the canopy is greater after flowering.

The accumulated solar energy incident on the canopy faces increases until the onset of ripening.

Vineyards trained to a vertical trellis system in the north-south direction provide favorable sunlight exposure to leaves and fruits and are promising in quality and productivity.

\section{ACKNOWLEDGMENTS}

The authors wish to thank the Coordination for the Improvement of Higher Education Personnel (CAPES) for the financial support, and the Federal University of Santa Catarina (UFSC/RGV) and the State Meteorology Service (EPAGRI/CIRAM) for providing the opportunity of carrying out the present research.

\section{REFERENCES}

ASSIS, J.S.; LIMA FILHO, J.M.P.; LIMA, M.A.C. Fisiologia da videira. In: FEIRA NACIONAL DA AGRICULTURA IRRIGADA, 2004, Petrolina.

BORGHEZAN, M.; GAVIOLI, O.; PIT, F.A.; SILVA, A.L. Vegetative and productive behavior of grapevines and composition of grapes in São Joaquim, Santa Catarina, Brazil. Pesquisa Agropecuária Brasileira, Brasília, v.46, n.4, p.398405, 2011.

BORGHEZAN, M.; GAVIOLI, O.; VIEIRA, H.J.; SILVA, A.L. Shoot growth of Merlot and Cabernet Sauvignon grapevine varieties. Pesquisa Agropecuária Brasileira, Brasília, v.47, n.2, p.200207, 2012.

BORGHEZAN, M.; VILLAR, L.; DA SILVA, T.C.; CANTON, M.; GUERRA, M.P.; CAMPOS, C.G.C. Phenology and vegetative growth in a new production region of grapevines: case study in são Joaquim, Santa Catarina, southern Brazil. Open Journal of Ecology, Irvine, v.4, n.6, p.321 -335, 2014. 
BRIGHENTI, A.F.; MALINOVSKI, L.I.; STEFANINI, M.; VIEIRA, H.J.; SILVA, A.L. Comparison between the wine producing regions of São Joaquim-SC, Brazil and San Michele all'AdigeTN, Italy. Revista Brasileira de Fruticultura, Jaboticabal, v.37, n.2, p.281-288, 2015.

CAMPOS, C.G.C.; VIEIRA, H.J.; BACK, A.J.; SILVA, A.L. The global solar radiation flow on altitude vineyards in São Joaquim, State of Santa Catarina. Revista Brasileira de Fruticultura, Jaboticabal, v.35, n.3, p.722-729, 2013.

CARDOSO, L.S.; BERGAMASCHI, H.; COMIRAN, F.; CHAVARRIA, G.; MARODIN, G.A.B.; DALMAGO, G.A.; MANDELLI, F. Padrões de interceptação de radiação solar em vinhedos com e sem cobertura plástica. Revista Brasileira de Fruticultura, Jaboticabal, v.32, n.1, p.161-171, 2010.

CARON, B.O.; LAMEGO F.P.; SOUZA V.Q.; COSTA E.C.; ELOY E.; BEHLING A.; TREVISAN R. Interceptação da radiação luminosa pelo dossel de espécies florestais e sua relação com o manejo das plantas daninhas. Ciência Rural, Santa Maria v.42, n.01, p.75-82, 2012.

ClOETE, H.; ARCHER, E.; HUNTER, J.J. Shoot heterogeneity effects on Shiraz/Richter 99 grapevines. I. vegetative growth. South African Journal of Enology and Viticulture, Dennesig, v.27, p.68-75, 2006.

EMBRAPA. Uvas viníferas para processamento em regiões de clima temperado. Bento Gonçalves: Embrapa Uva e Vinho, 2003. Disponível em: <http://www.cnpuv.embrapa.br/publica/sprod/ vasViniferasRegioesClimaTemperado $>$. Acesso em: fev. 2013.

MIELE A.; MANDELLI, F. Uvas viníferas para processamento em regiões de clima temperado. Bento Gonçalves: Embrapa Uva e Vinho, 2013. Disponível em: $<$ http://www.cnpuv.embrapa.br/publica/sprod/ UvaViniferasRegioesClimaTemperado/poda. html\#desfolha>. Acesso em: 13 dez. 2013.

PEDRO JÚNIOR, M.J.; SENTELHAS, P.C. Clima e produção. In: POMMER, C.V. (Ed.). Uva: tecnologia de produção, pós-colheita e mercado. Porto Alegre: Cinco Continentes, 2013. p.63-107.
PONI, S. Produrre quantita rispettando la qualita: il ruolo della gestione della chioma. Parte 2. InfoWine, Piacenza, v.5, p.1-3, 2005.

PONI, S.; CASALIN, L. Training system choice as relate to genotype, site vigour and grape quality targets. In: CONGRESSO LATINO AMERICANO DE VITICULTURA E ENOLOGIA, 10., 2005, Bento Gonçalves. Anais... Bento Gonçalves: EMBRAPA, 2005. p.173-185.

REYNOLDS, A.G.; HEUVEL J.E.V. Influence of grapevine training systems on vine growth and fruit composition: A review. American Journal of Enology and Viticulture, Davis, v.60, p.251-268, 2009.

SANTOS, H.P. Aspectos ecofisiológicos na condução da videira e sua influência na produtividade do vinhedo e na qualidade dos vinhos. Bento Gonçalves: Embrapa Uva e Vinho, 2006. 9p.

SCARPARE, F.V. Determinação de índices biometeorológicos da videira 'Niagara Rosada' (Vitis labrusca L.) podada em diferentes épocas e fases do ciclo vegetativo. 2007. Dissertação (Mestrado em Agronomia) - Escola Superior de Agricultura “Luiz de Queiroz", Universidade de São Paulo, Piracicaba, 2007.

SMITHYMAN, R.P.; HOWELL, G.S.; MILLER, D.P. Influence of canopy configuration on vegetative development, yield, and fruit composition of Seyval blanc grapevines. American Journal of Enology and Viticulture, Davis, v.48, n.4, p.482-491, 1997.

SONG, J.; SMART, R.; WANG, H.; DAMBERGS, B.; SPARROW, A.; QIAN, M.C. Effect of grape bunch sunlight exposure and UV radiation on phenolics and volatile composition of Vitis vinifera L. cv. Pinot noir wine. Food chemistry, Berlin, v.173, p.424-431, 2015.

SRINIVASAN, C.; MULLINS, M.G. Fisiologia do florescimento na videira: uma revisão. Campinas: IAC, 2000. 27 p.

VIEIRA, H.J.; BACK, A.; SILVA, A.L.; PEREIRA, E.S. Comparação da disponibilidade de radiação solar global e fotoperíodo entre as regiões vinícolas de Campo Belo do Sul-SC, Brasil e Pech Rouge, França. Revista Brasileira de Fruticultura, Jaboticabal, v.33, n.4, p.1055-1065, 2011. 